\title{
A RESPONSABILIDADE CIVIL AMBIENTAL NA INGLATERRA
}

\author{
ENVIRONMENTAL LIABILITY IN ENGLAND
}

\author{
Hebert Alves Coelho \\ Escola Superior Dom Helder Câmara - ESDHC - Belo Horizonte - Minas Gerais - \\ Brasil \\ Elcio Nacur Rezende \\ Escola Superior Dom Helder Câmara - ESDHC - Belo Horizonte - Minas Gerais - \\ Brasil
}

\begin{abstract}
Resumo: $O$ presente artigo analisa a responsabilidade civil ambiental na Inglaterra, demonstrando a evolução desse tipo de responsabilidade no país desde o seu surgimento até os dias atuais. Procura proporcionar uma visão coerente e abrangente da aplicação da responsabilidade objetiva na Inglaterra, inclusive com a constatação da importância que esse país confere às Teorias do Risco. Para isso, o artigo baseia-se, principalmente, nos precedentes judiciais, com destaque para o caso Ryland vs. Flecher e no Regulamento de Danos Ambientais (Prevenção e Reparação ) de 2009, que introduziu no ordenamento jurídico inglês a Diretiva 2004/35 do Parlamento Europeu. Buscou-se compreender o problema por meio de raciocínio dedutivo, com vertente metodológica jurídico-teórica, alicerçando-se na análise de doutrinas e artigos relacionados ao tema.
\end{abstract}

Palavras-chave: Responsabilidade civil ambiental - Inglaterra.

Abstract: This paper analyzes the environmental liability in England, showing the evolution of this type of liability in the country since its inception to the present day. It seeks to provide a coherent and comprehensive approach to the implementation of strict liability in England, including the verification of compliance by that country to Risk Theory created. For this, the article is based mainly on judicial precedents, especially the Ryland vs. Fletcher case and environmental damage regulations (prevention and repair) 2009, entered the English legal system Directive 2004/35 of the European Parliament. We tried to understand the problem through the deductive method, basing on the analysis of doctrines and articles related to the topic.

Key words: Environmental liability - England 


\section{Introdução}

A responsabilidade civil foi concebida, inicialmente, com base no princípio de que uma pessoa que causa danos a outra com algum grau de culpa deve repará-los. Esta clássica responsabilidade civil tem se desenvolvido, em um grande número de países, para introduzir, em algumas situações, um novo tipo de responsabilidade: a responsabilidade objetiva, que dispensa a perquirição de culpa.

Uma das hipóteses de aplicação da responsabilidade civil objetiva é justamente a que decorre de prejuízos ambientais. Esta responsabilidade dispensa a perquirição da culpa pelos danos ambientais, onde, geralmente, atividades de risco têm sido desenvolvidas (MCKENNA, 1996).

Há, no Brasil, grande discussão doutrinária e mesmo jurisprudencial a respeito das teorias que tratam da responsabilidade civil ambiental. Não se discute que a responsabilidade é a objetiva, mas sim, discute-se qual o tipo de responsabilidade objetiva é a adequada. Alguns defendem a aplicação da teoria do risco integral, enquanto outros a teoria do risco criado ou risco administrativo.

É certo que a teoria que trata da responsabilidade objetiva pela Teoria do Risco Integral acaba por prevalecer na jurisprudência e doutrina brasileiras, já que muito mais protetiva do meio ambiente, direito fundamental de todos.

Com o propósito de contribuir com esta discussão, constata-se a importância de se aferir como, em regra, a responsabilidade civil ambiental é tratada no plano internacional, em especial diante de diretiva europeia que pretende uniformizar essa forma de tratamento no âmbito europeu.

Nesse contexto, importante o estudo da responsabilidade civil por danos ao meio ambiente na Inglaterra, já que foi neste país que o meio ambiente começou a ser alterado com maior intensidade, a partir da Revolução Industrial iniciada no século XVIII (DELGADO, 2008).

Foi também na Inglaterra, já no século XIX, surgiu a responsabilidade objetiva por danos ao meio ambiente, que teve grande repercussão em outros países do mundo. 
A responsabilização civil objetiva por danos ao meio ambiente é uma tendência mundial e inegavelmente representa uma evolução da responsabilização civil subjetiva clássica.

$O$ presente trabalho pretende identificar e analisar o surgimento da responsabilidade civil ambiental, com foco na análise do acolhimento da responsabilidade objetiva, em especial na Inglaterra, procurando ainda explicitar sua evolução ao longo do tempo e sua relevância para a efetiva tutela do meio ambiente.

É necessário ir muito além da análise da legislação ambiental inglesa. É explorada outras fontes do direito na Inglaterra, como os precedentes judiciais (case law) e a regulamentação internacional incorporada no ordenamento jurídico inglês.

\section{A relevância da Responsabilidade Civil Objetiva em matéria ambiental}

A responsabilidade civil ambiental esteve, em sua origem, intrinsecamente ligada à ideia de culpa. Pela teoria da responsabilidade subjetiva não há responsabilidade sem culpa. Somente haveria responsabilidade quando alguém houver sofrido prejuízo causado a outrem de forma intencional ou, ao menos, com culpa (imprudência, negligência ou imperícia).

Segundo CUSTÓDIO (2006, p. 220): “A concepção clássica da responsabilidade subjetiva, como a teoria da autonomia de vontade, procede de uma filosofia que concebe o homem como sendo dono de uma vontade consciente e possuidor de seu livre-arbítrio". Expõe ainda Von Ihering, citado por Custódio (2006, p. 223), a fórmula " sem culpa, nenhuma reparação".

O foco da responsabilidade subjetiva não está na reparação do dano propriamente, mas sim na responsabilização daquele que agiu de forma intencional ou culposa e, com isto, acarretou danos. A existência da responsabilidade por culpa deve-se aos canonistas como uma forma de moralizar as condutas individuais e não a reparar danos (MACHADO, 2008, p. 342). 
Nada obstante, verificam-se diversas situações em que os prejuízos ambientais ocorrem, mesmo sem ter havido vontade ou culpa do causador do dano. A utilização da responsabilidade subjetiva, nesses casos, deixariam impunes os responsáveis pela degradação ambiental.

Diante da insuficiência desse sistema clássico de responsabilidade subjetiva, constata-se uma tendência de evolução em diversos países, incluindo a Inglaterra, para o sistema responsabilidade objetiva, em que o foco é a reparação do dano e a discussão de culpa passa a ser irrelevante.

Ao se promover a reparação do prejuízo procura-se o restabelecimento do equilíbrio rompido com a ocorrência do dano. A responsabilidade objetiva assume especial relevância diante da ocorrência de danos ambientais, já que contribui para uma maior efetividade na tutela do meio ambiente.

Villey citado por Machado (2008, p. 342) afirma:

O fundamento do regime romano de reparação de danos não é a culpa, mas a defesa de uma justa repartição entre os bens partilhados entre as famílias, isto é, de um justo equilíbrio. Suum cui que tribuere, aequabilitas. Quando intervém uma ruptura deste equilíbrio, um prejuízo contrário ao Direito e à Justiça ( damnum injuria datum) entra em jogo a justiça chamada "corretiva", cuja função será reduzir o desequilíbrio.

\section{3. $O$ surgimento da Responsabilidade Objetiva na Inglaterra}

$\mathrm{Na}$ Inglaterra, que possui uma constituição parcialmente costumeira (BONAVIDES, 2008, p. 84), há duas tradicionais fontes de leis: estatutos Statute Law, e as leis consuetudinárias - Common Law.

Os estatutos são derivados da legislação votadas pelo parlamento. Pode-se citar como estatutos o Environmental Protection Act, de 1990, referente a danos causados por um não autorizado depósito de resíduos e o Water Resorces Act, 1991, que proíbe seja despejada em águas qualquer material poluidor, entre outros estatutos.

Já as leis consuetudinárias são derivadas da jurisprudência - case law. Assim, a análise dos precedentes judiciais assume especial relevância no estudo da responsabilidade civil ambiental na Inglaterra. 
Demandas envolvendo o meio ambiente na Inglaterra geralmente eram trazidas por um destes três fundamentos: Negligência, Incômodo ou pela célebre regra Rylands v. Fletcher (MCKENNA, 1996). A negligência exige prova da culpa, razão pela qual não teve substancial impacto na tutela ambiental. Deve provar que houve um rompimento do dever de cuidado pelo réu, causando danos que eram razoavelmente previsíveis.

A ofensa pelo incômodo é basicamente um ato ou omissão em certa terra que interfere desarrazoadamente no uso ou no direito da terra de outra pessoa. Em alguns casos a ofensa pelo aborrecimento pode gerar inclusive responsabilização criminal como na contaminação da água potável. O Environmental Protection Act, 1990, estabelece uma lista das categorias de aborrecimentos que podem ser requeridas para serem minorados (MCKENNA, 1996).

O caso decidido pela Câmara dos Lordes (House of Lords), Ryland v. Fletcher, ocorrido em 1868 teve e ainda tem uma relevante repercussão na responsabilidade civil ambiental na Inglaterra. Até a ocorrência deste importante precedente judicial aplicava-se apenas a responsabilidade subjetiva baseada na negligência ou no incômodo.

O caso Ryland v. Fletcher, ao introduzir pela primeira vez, embora de forma ainda um pouco incipiente, a noção de responsabilidade objetiva, representou o início uma grande transformação no entendimento da responsabilidade ambiental na Inglaterra e, pode-se dizer, em outros países.

\subsection{Dos fatos precursores do surgimento da Responsabilidade Objetiva na Inglaterra}

Tendo a Revolução Industrial surgida na Inglaterra, com consequente a afetação do meio ambiente, foi natural que eclodisse, também neste país, um modelo de responsabilidade por danos ambientais que fosse mais eficaz na tutela do meio ambiente. Enquanto a Inglaterra do século XIX ficava mais industrializada, barragens eram construídas para fazer os rios navegáveis e gerar energia. 
Em 1850, na Inglaterra, ocorreu o colapso de uma barragem após uma pesada chuva matando 78 (setenta e oito) pessoas, destruindo cidades inteiras e deixando cerca de 7 mil pessoas sem casa ou trabalho. Apesar da extensão dos danos, havia pouco que a lei pudesse fazer criminal ou civilmente em face dos construtores da represa (GRAY, 2012, p. 165).

Outra catástrofe ocorreu em 1863. Na ocasião uma recente barragem começou a se romper enquanto enchia. Os avisos do desastre iminente chegaram tarde demais para 238 (duzentas e trinta e oito) pessoas que viviam abaixo da represa e que morreram dormindo em suas camas, além de desalojar mais de 20.000 (vinte mil) pessoas (GRAY, 2012, p. 165). Conforme expõe Simpson, citado por Gray (2012, p. 165), esses desastres influenciaram o famoso caso Ryland v. Fletcher.

\subsection{0 caso Ryland vs Flecher}

O caso Ryland versus Fletcher, ocorrido em 1868, na Inglaterra, inaugurou a possibilidade da responsabilização objetiva neste país. Nesse caso, Ryland construiu um reservatório de água em sua propriedade, vizinha da propriedade de Fletcher. Pouco depois de ser preenchida pela primeira vez, a represa inundou e causou danos nas minas de Fletcher, que se localizavam mais abaixo de onde estava o reservatório de Ryland.

Mesmo tendo reconhecido que o réu Ryland não foi negligente, a Câmara dos Lordes, entendeu que o mesmo deveria ser responsabilizado pelos danos. Esse tribunal concluiu que o represamento da água constitui uso não natural da terra e que haverá responsabilidade objetiva apesar do réu ter exercido todo o devido cuidado para prevenir que a fuga da água ocorresse (GRAY, 2012, p. 156).

De acordo com as leis inglesas da época, os réus eram inteiramente livres de culpa já que não houve negligência porque a água permaneceu no reservatório antes do rompimento em direção às minas e não houve incômodo porque a inundação não foi contínua ou ocorria com frequência (PROSSER, 1942, p. 401-402) 
O caso Ryland foi criado em resposta a outros rompimentos de represas e catastróficas inundações ocorridas nos anos de 1850 e 1860 que foram muito mais trágicos que o caso Ryland. Havia, pois, o entendimento de que o caso Ryland deve ser aplicado nas situações ligadas a rompimentos de reservatórios. A responsabilidade civil baseada no caso Ryland tem grande impacto nas situações em que ocorriam impactos ambientais. Basta pensar uma situação em que ocorre vazamento de substâncias tóxicas de uma fábrica atingindo um rio próximo e causado a morte da vida aquática. A esta responsabilidade civil pela degradação ambiental pode-se aplicar, na Inglaterra, a regra do caso Ryland.

Nas palavras de GRAY, 2012, p. 154:

\begin{abstract}
O conceito moderno de responsabilidade objetiva originou na Inglaterra em um caso onde as águas que haviam sido represadas em um reservatório recém-construído inundaram uma subterrânea mina de carvão na vizinhança da propriedade. Foi através desse caso que o judiciário pela primeira vez começou a produzir um coerente esquema de responsabilidade civil por perigosos trabalhos públicos e privados, como por exemplo, reservatórios de águas. A aplicação da responsabilidade objetiva permite ao tribunal impor responsabilidade sem considerar se o réu é negligente ou se ele intencionava causar o dano. Desta forma, em um caso de responsabilidade objetiva, o demandante não precisa provar se houve negligência ou intenção.
\end{abstract}

Assim, a responsabilidade objetiva surgiu na Inglaterra em razão dessa decisão judicial ocorrida na Inglaterra no século XIX para impor responsabilidade ao réu que, ao praticar uma atividade perigosa (construção de um reservatório), mesmo sem intenção ou culpa, produz dano na propriedade vizinha.

\footnotetext{
Esta significativa e controversa regra de responsabilidade, primeiro surgido em um caso de inundação de reservatório, é baseada na crença que algumas atividades são tão arriscadas que eles clamam pela responsabilidade objetiva mais do que a responsabilidade baseada na culpa (GRAY, 2012, p. 153, tradução nossa).
}

Trata-se, assim, de um caso muito específico de responsabilidade objetiva para os proprietários por substâncias (em seu uso não natural) que escapam de suas terras e danificam as terras de outros. Para haver a responsabilidade objetiva eram necessária a ocorrência de alguns elementos 
como uso não natural da terra, o escape de uma substância perigosa e ocorrência de danos em outra propriedade.

A pessoa que cria uma situação perigosa, que pode implicar em escape de substâncias, deve ser responsabilizada por eventuais danos, mesmo sem perquirir dolo ou culpa, caso ocorra tal escape.

A Câmara dos Lordes, tribunal inglês, considerou que o réu era responsável objetivamente porque introduziu um uso não natural de suas terras para outros propósitos para os quais as terras geralmente são usadas.

A aplicação da responsabilidade objetiva exigia, pois, três requisitos: o réu deve trazer para suas terras algo perigoso; o perigo deve escapar das terras do réu para atingir as terras do autor; o uso que o réu fazia da coisa perigosa deve ser não natural. A aplicação da responsabilidade objetiva nasceu, desta forma, de forma bastante restrita e limitada.

A despeito do surgimento ainda tímido da responsabilidade objetiva, fica claro a insuficiência da ideia de culpa como fundamento das obrigações para reparar um dano. Se uma pessoa sofreu um dano em razão da atividade de outra, um equilíbrio foi rompido e deve ser restabelecido, ainda que 0 causador do dano não tenha praticado o ato com culpa.

\subsection{Do acolhimento da Teoria da Responsabilidade Objetiva pelo Risco Criado pelo caso Ryland e sua aplicação na ocorrência de danos ambientais}

Releva notar que o nascimento da responsabilidade objetiva na Inglaterra não afastou o reconhecimento das excludentes de causalidades. A teoria do Risco Integral, na qual se admite a responsabilidade civil ambiental do causador dos danos ambientais independentemente de considerações sobre as excludentes de causalidade como a força maior, culpa exclusiva da vítima ou fato de terceiros, atualmente prevalente na jurisprudência brasileira, foi repudiada na Inglaterra.

Os estudiosos da lei da época consideraram que havia dois possíveis métodos que os réus poderiam fugir da responsabilidade: demonstração que a 
fuga da substância foi por culpa do réu ou que foi uma consequência do ato de Deus.

\begin{abstract}
Quem, para seus próprios propósitos, traz para sua terra e coleta e mantém lá qualquer coisa em que é possível causar prejuízo se escapar, deve manter isto sob seu próprio risco, e, se ocorrer o escape, ele é, a primeira vista, responsável pelo dano como consequência pelo escape. Ele pode apenas se desculpar demonstrando que a fuga foi por culpa do próprio réu, ou talvez que a fuga foi uma consequência de uma força maior, um ato de Deus (SMITH, 1917, p. 410).
\end{abstract}

Trata-se, pois, da adoção da responsabilidade objetiva pelo Risco Criado (que admite as excludentes do nexo causal como a culpa exclusiva da vítima e a força maior) e não pelo Risco Integral. Responsabilidade objetiva não significa responsabilidade absoluta ou automática.

A aplicação da incipiente responsabilidade objetiva, independentemente da existência de culpa, surgida com o Caso Ryland, mesmo que de forma limitada.

O entendimento da possibilidade da aplicação da responsabilidade objetiva desenvolvida pelos tribunais ingleses foi negada em várias jurisdições. Apesar de sofrer sérias resistências, teve e ainda hoje tem influência em outros casos análogos.

\title{
3.4 Da resistência à utilização da Responsabilidade Objetiva
}

Na Escócia, a responsabilidade objetiva foi descrita como uma heresia que deve ser extirpada (CAMERON, 2004, p. 119).

Nos Estados Unidos da América algumas jurisdições imediatamente adotaram a doutrina estabelecida pelo caso Rylands v. Fletcher, enquanto outras rapidamente a rejeitaram. Grande parte das críticas resultou da crença equivocada que no caso Ryland, a responsabilidade é absoluta e aplicável a qualquer caso de fuga de algo que causa danos (GRAY, 2012, p. 158).

Percebia-se erroneamente o referido precedente judicial como uma hipótese de responsabilidade objetiva pelo Risco Integral, sem possibilidade de se excluir a responsabilidade pelo rompimento do nexo causal, como nos casos de caso fortuito ou fato de terceiros. 
A ideia de que o réu poderia ser responsabilizado de forma absoluta, mesmo em razão de qualquer situação que escapava ao seu controle era bastante repudiada e considerada inapropriada para uma sociedade progressiva.

\section{Da evolução da Responsabilidade Objetiva na Inglaterra}

Muitos dos Tribunais, mesmo na Inglaterra, que rejeitaram a responsabilidade objetiva do caso Ryland, a tem aceitado sob o nome de incômodo (GRAY, 2012, p. 159). Independente do nome, trata-se de uma forma de responsabilidade objetiva em que o réu pode ser responsabilizado na ausência de qualquer conduta negligente de sua parte.

Com o tempo, os demandantes viram a aplicação da chamada regra do Ryland em uma longa lista de situações na qual supostas substâncias perigosas podem causar sérios danos se ocorrer o escape de onde 0 proprietário das terras as mantém, incluindo, além das águas represadas, a utilização de gás, eletricidade, líquidos inflamáveis, explosivos (como no uso de dinamites), pilhas de entulho que podem escorregar, vegetação venenosas, substâncias químicas perigosas, a manutenção de neve acumulada em um penhasco, atividades como escavação, direção de veículos sobrecarregados nas autoestradas, emissão de fumaça dos fogões, forno de coque ${ }^{1}$, direção de veículos que emitem faíscas (GRAY, 2012, p. 159).

Pode-se citar ainda a manutenção de neve no telhado, o colapso de alguma construção ou muro, uma calçada de gelo criado por um vazamento de água ou a utilização de fogo que pode se espalhar para a propriedade vizinha provocando a destruição da vegetação e morte de animais ou atividades passíveis de acarretar contaminação da terra, ainda da água subterrânea e até mesmo a fabricação de produtos defeituosos.

\footnotetext{
${ }^{1}$ Equipamento usado para a produção de coque, que é um derivado de carvão.
} 
Desta forma, há uma longa lista de circunstâncias envolvendo coisas perigosas que podem causar prejuízos em caso de escape do local em que se encontram. Em todas essas situações, possível a aplicação da regra de Ryland.

Assim, embora concebida, inicialmente, para o represamento de águas, o mesmo raciocínio pode ser usado para uma série de situações análogas passíveis de acarretar danos ambientais a fim de se aplicar a responsabilidade objetiva ambiental.

\subsection{Da necessidade da ocorrência do elemento previsibilidade}

Foi introduzido, ainda, o elemento da previsibilidade nos tribunais ingleses. A Câmara dos Lordes em 1994, no caso Cambridge Water Company v. Easter Counties Leather Public Liability Company considerou o réu não era responsável por uma contaminação porque entendeu que, ao tempo em que ele estocou, em 1977, grandes quantidades de produtos perigosos em sua propriedade, não era previsível que pequenas porções desses produtos iriam causar quaisquer danos ambientais, com sua infiltração no solo. Neste caso concluiu que é apropriado agora tomar em consideração a previsibilidade dos danos como um pré-requisito da responsabilidade por danos sob a regra do Ryland (GRAY, 2012, p. 172) .

Desta forma, tem-se aplicado a responsabilidade objetiva quando o réu está no controle ou é responsável por algo arriscado (seja uma represa, uma substância ou animal perigosos ou um defeito em um produto) e quando o demandante impõe ao réu um sério risco desconhecido/inevitável, mas previsível e que, em caso de escape, Ihe cause um dano (GRAY, 2012, p. 196)

Mesmo não se atendo apenas aos casos de danos causados pelas represas, constata-se ainda uma aplicação restrita da responsabilidade objetiva pela utilização da regra Ryland.

\subsection{Da atual aplicação da regra Ryland na Inglaterra}


Nada obstante, mesmo hoje o caso Rylands v. Fletcher é aplicado na Inglaterra. O Tribunal de Justiça Real, em decisão proferida em outubro de 2012, no caso Stannard v. Gore, discorreu longamente sobre o caso Ryland.

No caso Stannard v. Gore, decidido pelo Tribunal inglês em 2012, o fogo causado por problemas elétricos ocorridos em uma instalação repleta de pneus pertencente ao Sr. Stannard, se espalhou com grande rapidez para instalações próximas, de propriedade do Sr. Gore.

O juiz, em primeira instância, constatou, nesse caso, que o réu, Sr. Stannard, não foi negligente nem pelo início nem pela propagação do fogo. Considerou-se que, embora os pneus não sejam em si inflamáveis, os mesmos podem inflamar-se com facilidade, queimando rápida e intensamente. Considerou-se ainda que havia um previsível risco de incêndio, com o estoque desordenado e em grande quantidade de pneus para o tamanho das instalações. Desta forma, apesar de reconhecer não ter havido negligência, entendeu o juiz inglês pela responsabilidade objetiva do réu pela aplicação da regra do Rylands v. Flecher, já que o estoque de pneus configurou um elevado risco de perigo e, ainda, representou um uso não natural da terra.

Após a interposição de recurso pelo réu, Sr. Stannard, o Tribunal inglês, por unanimidade, discordou do juiz de primeira instância, entendendo não haver, na realidade, a possibilidade da aplicação da regra Rylands v. Flecher já que os pneus, em si, não são objetos excepcionalmente perigosos. Segundo a Corte, o que escapou foi o fogo e não os pneus. Além disso, o réu estava em seu uso normal das instalações, já que é fornecedor de pneus ${ }^{2}$.

Apesar da restrita aplicação da responsabilidade objetiva pelos tribunais ingleses pela aplicação da regra Ryland, existe entendimento de que a responsabilidade objetiva é flexível o suficiente para ser aplicada a qualquer atividade que implique em expor outros a um desarrazoado risco de dano, como no caso em que os pais deveriam ser responsabilizados objetivamente por danos causados por uma criança menor, por analogia aos danos causados por animais que invadem propriedade alheia (ANDERSON, 1978, p. 106).

\footnotetext{
${ }^{2}$ Decisão proferido pelo Royal Court of Justice na Inglaterra.
} 
Assim, surge, inclusive, entendimento pela possibilidade da aplicação da regra da responsabilidade objetiva pelo simples exercício de atividades de risco.

\subsection{Da Diretiva 2004/35 do Parlamento Europeu e do Conselho}

O direito inglês, baseado na common law, já conhece e aplica, desde o século XIX, a responsabilidade objetiva, seja pela utilização do precedente judicial ocorrido no julgamento Rylands v. Fletcher, seja pelo entendimento que se trata de uma especial forma de incômodo. Nada obstante, observa-se que a aplicação da responsabilidade objetiva por danos ao meio ambiente ainda era aplicada a situações bastante restritas e limitadas.

Segundo BENDRAN E MAYER (2013, p. 77) em 21 de abril de 2004, o Parlamento Europeu através da Diretiva 2004/35 estabeleceu diretrizes voltadas para os Estados-Membros da União Europeia sobre a responsabilidade ambiental em termos de prevenção e reparação dos danos ambientais.

Embora essa diretiva devesse ter sido recepcionada pelos 25 Estados Membros da União Europeia até abril de 2007, a mesma somente foi incorporada ao direito inglês em $1^{\circ}$ de março de 2009, através do Regulamento de Danos Ambientais Prevenção e Reparação. Este regulamento transporta as previsões da Diretiva 2004/35 para dentro das leis na Inglaterra.

Os sistemas de responsabilidade ambiental dos diversos EstadosMembros da União Europeia variavam muito quanto à responsabilização pelos danos ambientais e às exigências de sua reparação. Em 2004, a União Europeia procurou instituir um regime mais uniforme de prevenção e reparação dos danos ambientais através da adoção dessa relevante Diretiva 2004/35, relativa à responsabilidade ambiental em termos de prevenção e reparação de danos ambientais.

Essa legislação inovadora estabelece pela primeira vez na União Europeia, um regime de responsabilidade global para os danos ambientais, assente no princípio do poluidor-pagador.

A proteção dos recursos naturais da Europa (espécies e habitats protegidos, água e solo) e dos serviços ecossistêmicos por eles 
proporcionados é em geral reconhecida como um fator importante para que a economia de um Estado e para que a sociedade se desenvolva de forma saudável.

A Diretiva estabelece uma distinção entre dois tipos de operadores: os envolvidos em atividades ocupacionais perigosas, enumeradas em seu anexo $\mathrm{III}^{3}$ e os envolvidos em todas as outras atividades ocupacionais. Cada tipo dá

\section{${ }^{3}$ ANEXO III}

A presente directiva é aplicável:

Aos danos ambientais causados por qualquer das actividades ocupacionais enumeradas no Anexo III e à ameaça iminente daqueles danos em resultado dessas actividades;

1. A exploração de instalações sujeitas a licença, nos termos da Directiva 96/61/CE do Conselho, de 24 de Setembro de 1996, relativa à prevenção e controlo integrados da poluição (1). Ou seja, todas as actividades enumeradas no Anexo 1 da Directiva 96/61/CE, com excepção das instalações ou partes de instalações utilizadas para a investigação, desenvolvimento e ensaio de novos produtos e processos.

2. Operações de gestão de resíduos, incluindo a recolha, o transporte, a recuperação e a eliminação de resíduos e resíduos perigosos, incluindo a supervisão dessas operações e o tratamento posterior dos locais de eliminação, sujeitas a licença ou registo, nos termos da Directiva 75/442/CEE do Conselho, de 15 de Julho de 1975, relativa aos resíduos, e da Directiva 91/689/CEE do Conselho, de 12 de Dezembro de 1991, relativa aos resíduos perigosos.

Estas operações incluem, entre outras, a exploração de aterros nos termos da Directiva 1999/31/CE do Conselho, de 26 de Abril de 1999, relativa à deposição de resíduos em aterros , e a exploração de instalações de incineração nos termos da Directiva 2000/76/CE do Parlamento Europeu e do Conselho, de 4 de Dezembro de 2000, relativa à incineração de resíduos.

Para efeitos da presente directiva, os Estados-Membros podem decidir que estas operações não incluam o espalhamento de lamas de águas residuais provenientes de instalações de tratamento de resíduos urbanos, tratadas segundo normas aprovadas, para fins agrícolas.

3. Todas as descargas para as águas interiores de superfície que requeiram autorização prévia, nos termos da Directiva 76/464/CEE do Conselho, de 4 de Maio de 1976, relativa à poluição causada por determinadas substâncias perigosas lançadas no meio aquático da Comunidade.

4. Todas as descargas de substâncias para as águas subterrâneas que requeiram autorização prévia nos termos da Directiva 80/68/CEE do Conselho, de 17 de Dezembro de 1979, relativa à protecção das águas subterrâneas contra a poluição causada por certas substâncias perigosas.

5. As descargas ou injecções de poluentes nas águas de superfície ou nas águas subterrâneas que requeiram licença, autorização ou registo nos termos da Directiva 2000/60/CE.

6. Captação e represamento de água sujeitos a autorização prévia, nos termos da Directiva 2000/60/CE.

7. Fabrico, utilização, armazenamento, processamento, enchimento, libertação para o ambiente e transporte no local de:

a) Substâncias perigosas definidas no n.o 2 do artigo 2.0 da Directiva 67/548/CEE do Conselho, de 27 de Junho de 1967, relativa à aproximação das disposições legislativas, regulamentares e administrativas respeitantes à classificação, embalagem e rotulagem das substâncias perigosas;

b) Preparações perigosas, definidas no n.o 2 do artigo 2.0 da Directiva 1999/45/CE do Parlamento Europeu e do Conselho, de 31 de Maio de 1999, relativa à aproximação das disposições legislativas, regulamentares e administrativas dos Estados-Membros respeitantes à classificação, embalagem e rotulagem das preparações perigosas; 
origem a um nível de responsabilidade diferente. Aos operadores envolvidos em atividades enumeradas no anexo III é aplicável um regime de responsabilidade objetiva. Significa isto que não é necessário determinar a culpa para o operador ser responsabilizado pelos danos causados ao solo, às águas e aos habitats e espécies protegidas.

A todos os outros operadores não envolvidos em atividades enumeradas no anexo III é aplicável um regime de responsabilidade baseada na culpa. Nesse último caso, é necessário determinar a culpa ou a negligência para que o operador possa ser responsabilizado.

Estão incluídas nas atividades previstas no anexo III, o operador de uma atividade profissional (com ou sem fins lucrativos) que exija uma licença no domínio da prevenção e do controle integrados da poluição, exija uma autorização/licença de tratamento de resíduos, efetue descargas no meio aquático, utilize ou transporte substâncias perigosas como, por exemplo, produtos químicos, esteja relacionada com captações de água, utilize,

c) Produtos fitofarmacêuticos definidos no n.o 1 do artigo 2.o da Directiva 91/414/CEE do Conselho, de 15 de Julho de 1991, relativa à colocação dos produtos fitofarmacêuticos no mercado:

d) Produtos biocidas definidos na alínea a) do n.o 1 do artigo 2.o da Directiva 98/8/CE do Parlamento Europeu e do Conselho, de 16 de Fevereiro de 1998, relativa à colocação de produtos biocidas no mercado ;

8. Transporte rodoviário, ferroviário, marítimo, aéreo ou por vias navegáveis interiores de mercadorias perigosas ou poluentes definidas no Anexo A da Directiva 94/55/CE do Conselho, de 21 de Novembro de 1994, relativa à aproximação das legislações dos Estados-Membros respeitantes ao transporte rodoviário de mercadorias perigosas, no Anexo da Directiva 96/49/CE do Conselho, de 23 de Julho de 1996, relativa à aproximação das legislações dos Estados-Membros respeitantes ao transporte ferroviário de mercadorias perigosas, ou na Directiva 93/75/CEE do Conselho, de 13 de Setembro de 1993, relativa às condições mínimas exigidas aos navios com destino aos portos marítimos da Comunidade ou que deles saiam transportando mercadorias perigosas ou poluentes.

9. Exploração de instalações sujeitas a autorização, nos termos da Directiva 84/360/CEE do Conselho, de 28 de Junho de 1984, relativa à luta contra a poluição atmosférica provocada por instalações industriais, no que respeita à libertação para a atmosfera de quaisquer das substâncias poluentes abrangidas pela referida Directiva.

10. Quaisquer utilizações confinadas, incluindo transporte, que envolvam microrganismos geneticamente modificados definidos pela Directiva 90/219/CEE do Conselho, de 23 de Abril de 1990, relativa à utilização confinada de microrganismos geneticamente modificados.

11. Qualquer libertação deliberada para o ambiente, incluindo a colocação no mercado ou o transporte de organismos geneticamente modificados definidos na Directiva 2001/18/CE do Parlamento Europeu e do Conselho.

12. Transferências transfronteiriças de resíduos, no interior, à entrada e à saída da União Europeia, que exijam uma autorização, ou seja, proibidas na acepção do Regulamento (CEE) n.o 259/93, de 1 de Fevereiro de 1993, relativo à fiscalização e ao controlo das transferências de resíduos no interior, à entrada e à saída da Comunidade. 
transforme, liberte substâncias ou preparações perigosas, produtos fito farmacêuticos ou produtos biocidas, liberte intencionalmente organismos geneticamente modificados no ambiente, transporte resíduos, produza resíduos de mineração, envolva a captura e a armazenagem de carbono.

Essas atividades têm uma responsabilidade objetiva pelos danos, ou pela ameaça iminente de danos, que a sua atividade cause à água, ao solo e às espécies protegidas de animais e plantas, bem como aos seus habitat naturais ${ }^{4}$.

Isto significa que não é necessário determinar a existência de culpa ou negligência da sua parte para ele ser responsável pela adoção de medidas de prevenção e reparação, bem como pelo pagamento dos respetivos custos.

Com a adoção da Diretiva 2004/35 do Parlamento Europeu, a Inglaterra claramente amplia a possibilidade da utilização da responsabilidade objetiva por danos ambientais para além da concepção restritiva do caso Ryland. Através das atividades listadas no anexo III, têm-se precisamente quais são as atividades perigosas a ensejar a responsabilidade objetiva, independentemente de considerações como fuga de substâncias e uso não natural da terra.

Assim, na Inglaterra, além dos estatutos legais que tratam da tutela do meio ambiente, tais como a Lei de Proteção Ambiental de 1990 (Environmental Protection Act, 1990 ), Lei de Recursos Hídricos de 1991 (the Water Resources Act, 1991 ) ou a Lei da Vida Selvagem e Campo de 1981 (the Wildlife and Countryside Act, 1981), chamados de statute law, e os precedentes judiciais, chamados de case law como no célebre caso Rylands v. Fletcher, pode-se citar ainda como fonte recente da tutela ambiental na Inglaterra os regulamentos, mais precisamente o Regulamento de Danos Ambientais (Prevenção e Reparação) de 2009, que introduziu a Diretiva 2004/35 no ordenamento jurídico inglês ampliando as hipóteses de incidência da responsabilidade objetiva nesse país.

\subsection{Do acolhimento da Teoria da Responsabilidade Objetiva pelo Risco Criado pela Diretiva 2004/35}

${ }^{4}$ Diretiva de Responsabilidade Ambiental 2004/35. 
Releva notar que, mesmo na Diretiva Europeia, tal como no caso Ryland, a responsabilidade é objetiva pelo Risco Criado, admitindo-se, portando, excludentes do nexo de causalidade.

Independentemente da atividade profissional do operador, este não é responsável se os danos forem causados por atos de conflito armado, hostilidades, guerra civil ou insurreição, fenómenos naturais extraordinários (de caráter excecional, irresistível e inevitável), atividades realizadas, principalmente, ao serviço da defesa nacional ou da segurança internacional, ou tendo em vista a proteção contra catástrofes naturais, causados por terceiros.

A adoção da teoria do Risco Integral, mesmo considerando ser mais protetiva ao meio ambiente, pode levar a uma grave sensação de injustiça em situações em que o causador do dano, não apenas não teve culpa, como ainda foi impelido por alguma circunstância da qual não tinha qualquer controle.

Dessa forma, a Diretiva 2004/35 do Parlamento Europeu, incorporada pela Inglaterra, permite que os causadores de danos ambientais possam afastar a responsabilidade ao invocar defesas razoáveis, como os danos ambientais causados por força maior (como tempestades e conflitos armados). Se, por exemplo, após uma tempestade, uma fábrica de produtos químicos liberarem substâncias perigosas no solo e na água, a mesma não poderá, em princípio, ser responsabilizada.

\section{Considerações finais}

A evolução das formas de responsabilidade civil ambiental subjetiva para a objetiva implica em uma tutela mais efetiva do meio ambiente já que a perquirição da culpa é despicienda. O meio ambiente ecologicamente equilibrado é direito fundamental de todos e, portanto, deve ser tutelado de forma efetiva a fim de se resguardar a dignidade do ser humano.

Estados Democráticos de Direito devem não apenas proclamar direitos, mas efetivamente garanti-los. Pouco adiantaria simplesmente 0 reconhecimento de determinado direito, como o direito ao meio ambiente 
ecologicamente equilibrado, se não haver instrumentos que concretizem eficazmente esta proteção.

Neste sentido, a responsabilidade subjetiva não seria suficiente para uma efetiva proteção aos danos ambientais, já que envolveria um fator dificultador, qual seja, a prova da existência da culpa do poluidor.

O precedente judicial Rylands vs. Fletcher representou o nascimento ou a origem da responsabilidade objetiva na Inglaterra (inclusive com influência em diversos outros países), com aplicação em situações envolvendo danos ambientais. Pode-se falar que, a partir deste marco, a tutela ambiental na Inglaterra passou a ser mais efetiva.

A responsabilidade objetiva surgiu ainda muito limitada, aplicando-se, em um primeiro momento, aos danos causados nos casos de rompimento de represas e, posteriormente, mas ainda de forma muito restrita, a outras situações a depender da implementação de alguns requisitos, como a necessidade do responsável fazer uso não natural de algo perigoso em sua propriedade que atinja propriedades alheias causando danos previsíveis.

Nada obstante, a responsabilidade objetiva foi ampliada pela incorporação nas leis inglesas da Diretiva 2004/35 do Parlamento Europeu que, em seu anexo 'Ill' prevê, detalhadamente, as situações em que ocorrem a responsabilidade ambiental objetiva, ou seja, a responsabilidade sem discussão de culpa.

Constatou-se que, tanto na aplicação da regra Ryland, quanto da Diretriz 2004/35, a adoção da responsabilidade civil ambiental objetiva pelo Risco Criado, ou seja, que a responsabilidade pode ser afastada em havendo circunstâncias que rompam com o nexo causal, como a força maior e fato de terceiro.

Apesar de pacífica a utilização da responsabilidade civil objetiva na Inglaterra diante da ocorrência de danos ambientais, deve-se ressaltar que a concepção da responsabilidade objetiva pelo Risco Integral não tem sido aceita neste país ante a percepção de que é excessiva.

Verifica-se que a responsabilidade civil ambiental objetiva é, certamente, um aprimoramento da clássica responsabilidade civil subjetiva e que há uma 
tendência a uma ampliação nas situações passíveis de se admitir este tipo de responsabilização.

Por fim, nota-se que tem prevalecido no ordenamento jurídico da Inglaterra o entendimento de que a teoria do Risco Criado é o sistema mais adequado para a tutela ambiental.

\section{Referências}

ANDERSON, Jon G. The Rylandes v. Fletcher Doctrine in America: Abnormally Dangerous, Ultrahazardous, ou Absolute Nuisance? Ariz, 1978. In: Guevara, David; Deveau, Frank J. Environmental Liability and Insurance Recovery. Estados Unidos da América, ABA, 2012 ( Orgs ).

BEDRAN K. M. e MAYER E. A. Responsabilidade Civil por Danos Ambientais no Direito Brasileiro e Comparado: Teoria do Risco Criado versus Teoria do Risco Integral. Veredas do Direito, Belo Horizonte, MG, vol. 10, №19, Jan/Jul 2013.

BONAVIDES, Paulo. Curso de Direito Constitucional, 23aㅡ ed, São Paulo, Malheiros, 2008.

CAMERON, Gordon. Scots and English Nuisance... Much the Same Thing? Edinburgh Law Review ( Edinburg University Press ), 2004

CUSTÓDIO, Helita Barreiro. Responsabilidade Civil por Danos ao Meio Ambiente. São Paulo, Millennium, 2006.

DELGADO, José Augusto. Responsabilidade Civil por Dano Moral Ambiental. Informativo Jurídico da Biblioteca Ministro Oscar Saraiva, v.19, n.01, jan../jun.2008. Disponível em < http://www.stj.jus.br/publicacaoinstitucional/index.php/informativo/article/view/57 $/ 61>$ Aceso em 10.04.15

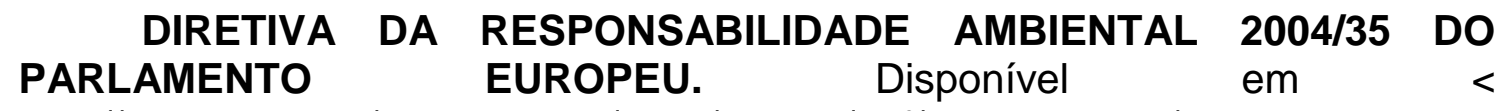
http://ec.europa.eu/environment/legal/liability/pdf/eld brochure/ELD\%20brochur e.pdf ) > Acesso em 13.04.15

GRAY, John S. Strict Liabiliy Judicially Imposed Civil Liability for Dangerous Public and Private Activities, p.154. In: Guevara, David; Deveau, 
Frank J. Environmental Liability and Insurance Recovery. Estados Unidos da América, ABA, 2012 ( Orgs ).

MACHADO, Paulo Affonso Lemme. Direito Ambiental Brasileiro. 16 ed. São Paulo, Malheiros, 2008.

MCKENNA, CMS Cameron. Study of Civil Liability for Environmental Damage. Londres, Junho 1996.

PROSSER, Willian L. Nuisance Without Fault, 20, Tex. L. Ver. 399, 401-02 ( 1942 ).In: Gray, John S. Strict Liabiliy Judicially Imposed Civil Liability for Dangerous Public and Private Activities, p.156. In: Guevara, David; Deveau, Frank J. Environmental Liability and Insurance Recovery. Estados Unidos da América, ABA, 2012 ( Orgs ).

ROYAL COURT OF JUSTICE. Stannard v. Gore. Disponível em < http://www.crownofficechambers.com/assets/docs/news/stannard_ta_wyvern_ty res_v_gore_2012_ewca_civ_1248.pdf > Acesso em 13.04.15

SIMPSON, A.W.B. Legal Liability for Bursting Reservoirs: The Historic Contexto f Rylands v.Fletcher, 13 J. Legal Stud. 209, 216 ( 1984 ).id at.223. In: Guevara, David; Deveau, Frank J. Environmental Liability and Insurance Recovery. Estados Unidos da América, ABA, 2012. p.165 (Orgs).

SMITH, Jeremiah. Tort and Absolute Liability: Suggested Changes in Classification, 30 Harv. L.Rev. 1942, p. 401-02. In: Guevara, David; Deveau, Frank J. Environmental Liability and Insurance Recovery. Estados Unidos da América, ABA, 2012 ( Orgs ).

\section{THE ENVIRONMENTAL DAMAGE. Prevention and Remediation Regulations $2009 \quad-\quad$ Disponível em < https://www.gov.uk/government/uploads/system/uploads/attachment_data/file/2 21095/pb13895-indepth-guide-regs09.pdf > Acesso em 13.04.15.}

VILLEY, Michel. La Responsabilieté a travers les Ages. Paris, pp.7589. In: Machado, Paulo Affonso Lemme. Direito Ambiental Brasileiro. 16 $6^{\underline{a}}$ ed. São Paulo, Malheiros, 2008. p.342. 